\title{
災害時における喘息・アレルギー患児への対応と問題点 一東日本大震災での報告と今後への提言一
}

\section{4. 現地支援}

\author{
松井 猛彦 \\ 東京都保健医療公社荏原病院小児科 \\ キーワード : アレルギー疾患, 喘息, 東日本大震災, 提言
}

（日小ア誌２011;25:734-738）

はじめに

2011 年 3 月 11 日, 東日本を襲った巨大地震とそ れに引き続く津波は，わが国に有史以来未曾有の被 害をもたらすと同時に，原発のメルトダウンによる 大量の放射性物質飛散という重大事故を引き起こ し，世界に強い衝撃を与えた。

今回の震災の特徵は, 1）広大な震災被害地域, 2) 多様な震災被害（大津波, 地震, 大火災, 原発重大 事故)，3）多様性な地域特性 (地勢, インフラ状況, 行政組織）としてまとめることが出来，極めて深刻 で多様な事態が広大な地域に同時発生した未曾有の 出来事であったと言えよう.

筆者は, 宮城県気仙沼市に現地医療救護班のリー ダーとして，4月 9 日から 4 月 14 日の間, 救援活動

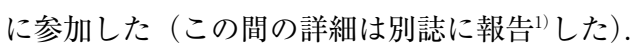

気仙沼市は, 地震 (震度 6 弱 5 強) とそれに引き 続く大津波, 流失した重油による市街地の大火災で, 沿岸部は壊滅的な被害を受け, 2011 年 6 月 16 日現 在, 死亡者 975 人, 行方不明者 495 人（全人口の約 $2 \%$ が死亡または行方不明), 住家 10,672 棟が被災し た.

沿岸部は，筆者が到着した時点でもその惨状は筆 舌に尽くし難かった.

本稿では, 現地の救援活動と見聞から, 震災時に おける喘息・アレルギー疾患への対応と問題点につ いて考えてみたい.
表 1 気仙沼市医療課題推移状況（2011 年 4 月 9 13 日）

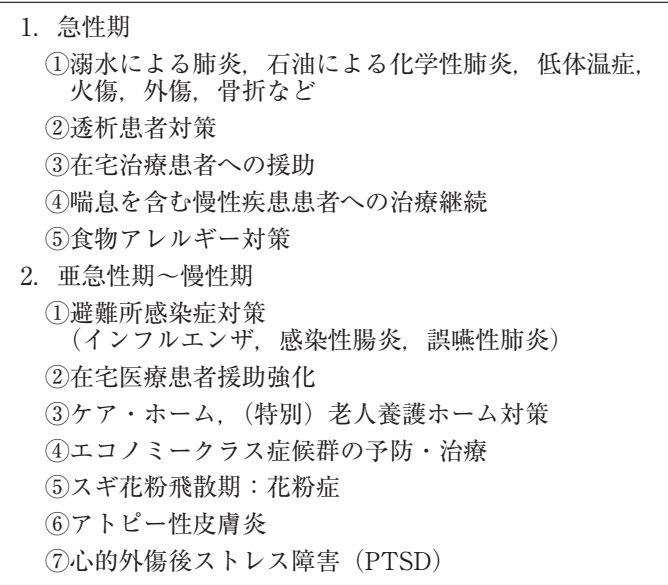

\section{1. 現地状況・救援活動}

気仙沼市における医療課題の状況の推移は, 仮に 急性期から覀急性期と慢性期 (回復期)に分けると, 報告・記事・伝聞などから, 表 1 のごとくまとめる ことができた.

今回の大震災における気仙沼市での死因の $90 \%$ 以上は救命が困難な溺死で, 当初, 病院・救護所で 求められたのは, 大津波とそれに引き続く石油製品 
の流失によって引き起こされた大火災による被害が 多く, 従来の大地震で多い外傷が少なかったのが特 徵的であったとされる。

震災発生後 48 時間以内の急性期には, 大震災に起 因した急性疾患に対する病院や救護所での対応と同 時に，入院中の患者や透析患者などへの対応が求め られた．主な避難所を拠点とする医療救援活動等が 行われた。在宅医療患者はインフラの壊滅や訪問看 護センターの機能が失われた中で孤立して厳寒の中 に取り残され, 裖創の悪化などを含め, 極めて厳し い状況下に置かれた。

亜急性期になると，避難所での感染症対策や慢性 疾患の治療継続, 在宅医療患者への支援が行われる ようになったままた，壊れた瓦礫を踏み分けている 間におこる釘の踏み抜きなど外傷による破傷風や工 コノミー症候群がみられるようになった。

筆者が現地入りした震災 1 ケ月後にはインフラの 回復が進みつつある回復期に入っており, 救援の医 薬品の整備が進み, また, 市内では何力所かの処方 箋薬局が再開しつつあり，災害時処方箋（大規模災 害時などで医師の受診や処方箋交付が困難な場合, 処方箋がなくても薬手帳や服用薬のシートがあれば 最寄りの薬局で薬剤を入手することができる一災害 時の処方箋医薬品の例外措置)に対応が可能になり, 一部の診療所・病院で受診が可能になっていた.

\section{2. アレルギー疾患の現地状況と問題点}

日本小児アレルギー学会は, 被災地の避難所にお ける小児アレルギー患児の状況や必要としているこ となどを把握し，救援活動に役立てることを目的に アンケート調査を実施することを筆者に依頼した. そこで，気仙沼の各避難所で医療救援を行っている 各チームに小児アレルギー患者を対象に質問表の配 布を依頼し，16 人（表 2$)$ から回答を得た.

避難所の悉皆調査ではないこと, 調査場所が避難 所に限られていたこと, 震災から 1 ケ月程度経って いたことなどから，さらに小児アレルギーの震災前 後の状況については調査を進める必要がある.

急性期には, 治療中断や大量のアレルゲンや大気 污染物質の飛散によって一部の喘息患者で喘息発作 の悪化がみられ, 食物アレルギー患児は急性期から 食材の入手に難渋した.

亜急性期に入ると, 季節はスギ花粉の飛散期を迎
え, 気仙沼の避難所でのアレルギー患者への聞き取 り調査では, アトピー性皮膚炎, 花粉症の訴えがあっ たが，投薬などで症状は比較的よくコントロールさ れる状態になっていた。

喘息患者には抗喘息薬が処方され，発作はコント ロールされるようになったが, 小児の散薬処方や電 動吸入器の不足が問題になったが, 分包された散薬 や吸入薬も次第に配備された.

乳幼児喘息に対する吸入ステロイド薬 · 液凨の投 与が器械や電力の問題で不可能な場合, 吸入補助器 具を使って定量噴霧式吸入器で代替えして吸入する 方法もあるが, 吸入補助器具が配置されていたもの のその利用率は低かったようである.

震災 1 ケ月後の回復期に入ると, 吸入器が大量に 搬入された。

アレルギー治療薬の入手が困難になった要因は, 急性期（初期）には薬剤や吸入器材, 動力がないと いったことがあげられたが, その後は, 集積した救 援医薬品などの整理と配分機能や処方医の不足，ア クセス手段が得られない, 遠慮して症状を訴えない, 救援活動に参加した医師の知識の不足によって同種 同効の薬剤が転用されなかったなどといった問題が みられた（表 $3 ）$.

アレルギー資料関連物資の入手困難度を模式的に 図 1 に示した。

われわれが到着した時点では，避難所に小児の姿 は比較的少なかった，小児の保護や泣き声，騒ぐと いったことに対する周囲への気兼ね，喘息や食物ア レルギーなどへの対応の必要性などから，伝手を 頼って一時避難したり, 被災自宅などで生活を送っ ていたのではないかと推測された.

\section{3. 情報に関する問題点}

震災現場では, 時間の経過とともに状況が急速に 変わり，医療ニーズも刻々変わってくる．これに対 応して医療救援活動を展開する必要がある.

これには，情報中枢を構築し，現地情報を収集し て解析しながら, 有効・効率的な対策を講じてゆく 必要がある。

今回の震災では, 先に述べたごとく, 広大な被災 地域, 多様な被災状況から, 情報の収集と処理が一 層求められたが, 救援出発前に, 現地の状況がなか なか伝わってこなかった. 


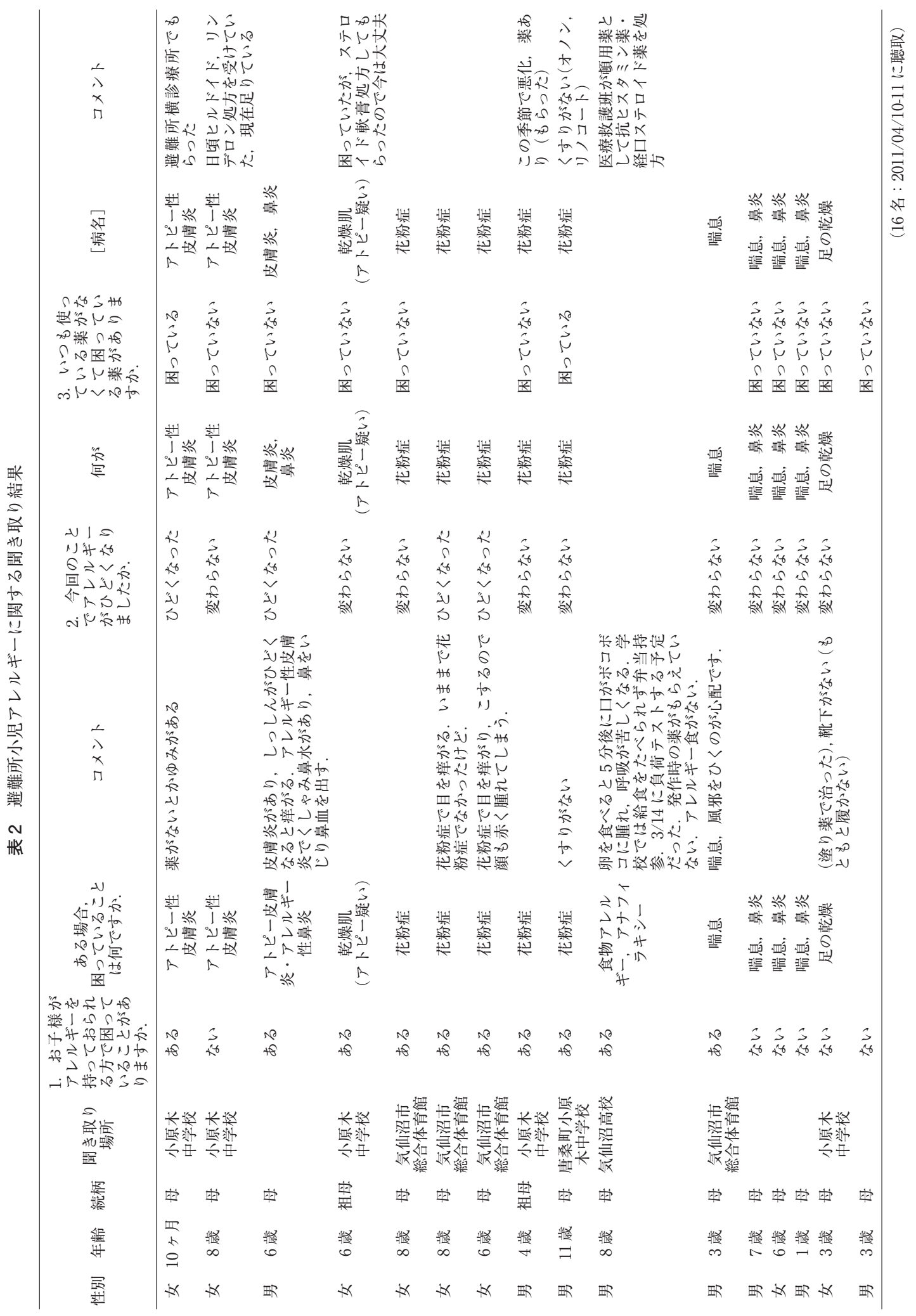


表3 東日本大震災におけるアレルギー疾患(気仙沼市・ 聞き取り・各種情報から)
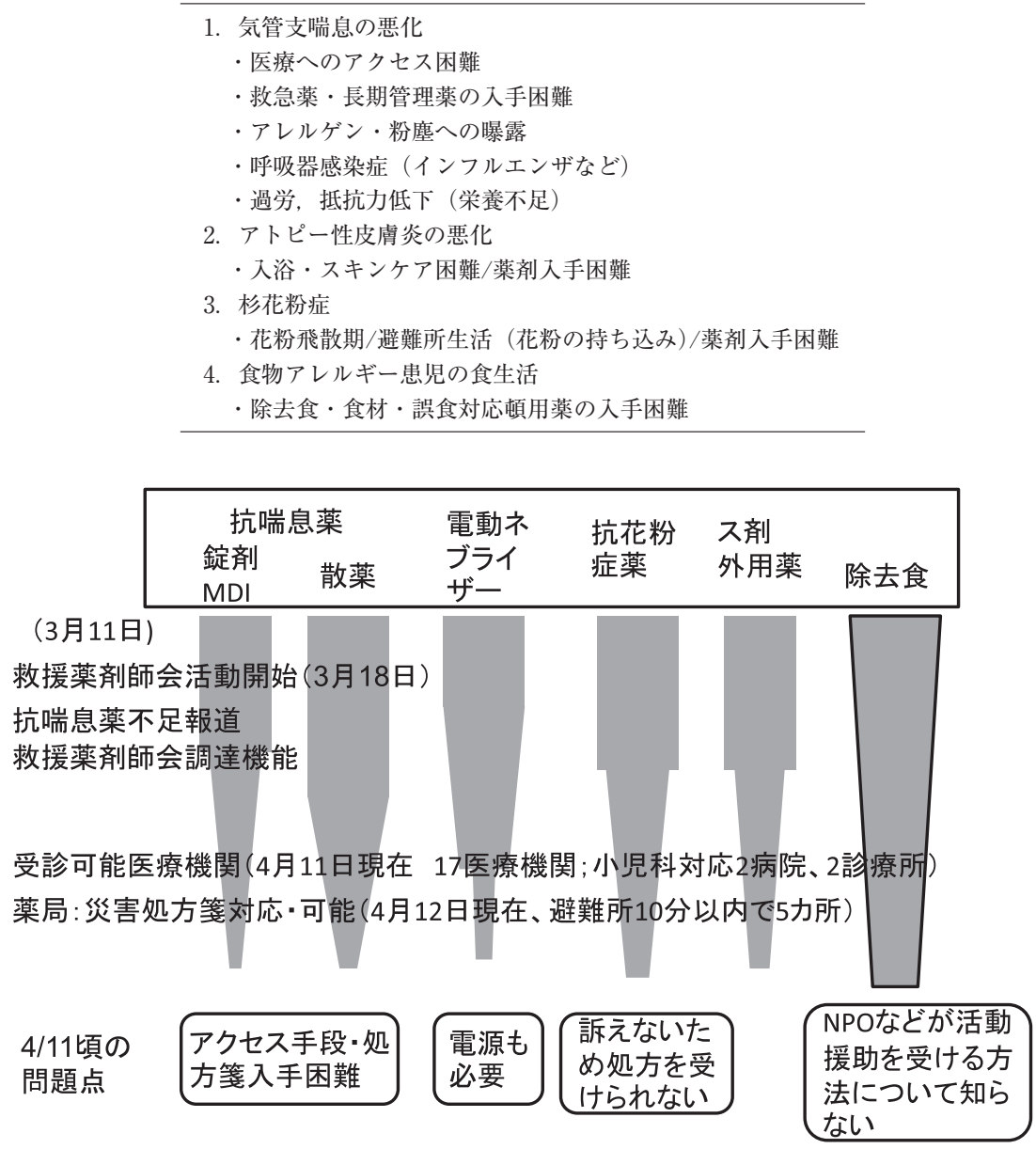

図 1 アレルギー治療関連物資入手困難度（気仙沼市：推定）

一方，現地からの断片的な情報への集中豪雨的な 対応は，過度な物資の集積と非効率性をもたらし， 災害現場へ不必要な負荷をかけることになる。

短期間の医療救援隊の交代は, 情報の共有と対応 の継続性に難をもたらし, 系統的な体制構築の必要 性を痛感させられた.

亜急性期になったら，なるべく早期に情報中枢を 立ち上げ，効率的な災害救助を図るべきであろう。 救急医療現場では, 医療資材の迅速, 的確な管理 · 提供が求められ，これには専門的知識が必要で, 看 護師, 薬剤師と共同してこれにあたる必要がある.

さらに，被災現地の事情に詳しいボランティアの 手助けなくしては, 救援活動はなかなか困難で, 気 仙沼では一関など周辺地区の現地ボランティアの貢
献は大きなものがあった.

\section{4. 今後の課題}

日本では, そう遠くない将来, 関東大地震, 東海・ 東南海・南海大地震など人口密集地域での巨大地震 の発生が危惧されている. 多数の被災が推測され, これに備えた個人の自主努力も求められる.

大震災に際しては, 第一撃から自身の身を守るこ が第一である。そして，安全な場所へ避難する。も し余裕があれば非常用品を携行する．喘息患者は防 塵マスクと常用薬, お薬手帳を加えておく.

震災医療では, 生命リスクの高い医療が優先され るのはやむを得ない. 
表 4 被災地におけるアレルギー患者留意事項

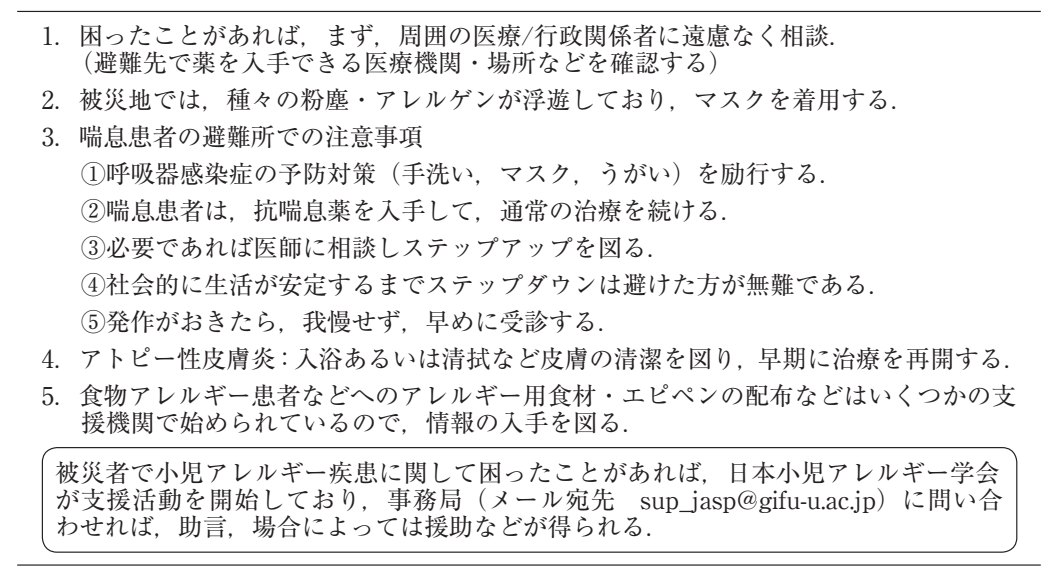

(松井猛彦 : 教育医療新聞 2011/4/25 に揭載)

その観点からアレルギー疾患をみると, (1)急性期 には中等症以上の喘息発作と(2)重症なアナフィラキ シー反応に優先度が最も高く, 次いで(3)重症な即時 型反応の既往がある食物アレルギー患児への除去食 供給が挙げられるであろう。さらに，(4)喘息患児へ の予防的薬物投与の継続, (5)アトピー性皮膚炎やア レルギー性鼻炎への対応となろう。

1)，(2)については DMAT で対応が可能であるが, (3)については保存食の開発, 個人や行政による備蓄, 効果的な供給体制の構築などが検討課題となる。

(4)については, 抗喘息薬の確保が問題になる. 阪 神・神戸大震災では, 救援医薬品が患者に十分供給 されるには 2 週間程度の時間が必要であったとされ ている.

患者による発作治療薬をふくむ常用薬の 1 ケ月程 度の備蓄と避難袋への準備, 災害時処方箋制度を有 効に利用するために「お薬手帳」またはそのコピー の携帯が求められる。

避難所における救援薬剤の供給体制の早期確立や 処方箋薬局の機能回復が求められる.

さらに, 電源や吸入器が使用できない場合, 乳幼 児に, 定量噴霧式吸入器と吸入補助器具を利用して 投与する方法など, 医師や医療従事者, 患者・家族 に教育しておく必要があろう.

患者の避難所での対応にあたっては, 表 4 が参考 になろう。

医療団体による救援活動には人的，資金的に限界
があり, 行政や NPO 団体との連携は欠かせない. 効 率的な連携を行うためにも, 情報の集約, 共有をア レルギー関係団体で行うべきであろう。また，アレ ルギー患者が震災に際し必要な情報を発信し, 救援 を得るシステムがなかった。

今回, 日本小児アレルギー学会, NPO 団体などが 個別に救援活動にあたったが，情報を集約し協力で きる体制を予め構築し，これを一般に周知しておく 必要がある.

\section{おわりに}

本稿は，筆者の体験した一地域における短期間の 医療救援活動の経験と見聞からの提言に過ぎない. より大きな立場から救援活動に携わり, 各地の救援 活動を俯瞰できる立場にあった県医療コーディネー ター, 厚生労働省など政府機関と事後検証を進め, 次の災害に備える必要がある.

また，大災害時におけるアレルギー患者の実態に ついては不明な点が多く, これを解明し, 有効な対 策を検討する必要がある.

\section{文献}

1）松井猛彦．被災地での医療活動一気仙沼におけ る災害医療活動に参加して，東京小児科医会報 2011;30 (6):41-46. 